\title{
Managing Our Past, Managing Our Future: Is there a "Right" Way of Remembrance?
}

\author{
Ruth Linn \\ The University of Haifa, Haifa, Israel
}

\begin{abstract}
In the spring of 1944, the Auschwitz-Birkenau death factory was still a top secret of the Third Reich and the Nazis used numerous ploys to entice their prospective victims into it. On April 7, 1944, two Slovak Jewish prisoners, Rudolf Vrba and Alfred Wetzler managed to escape Auschwitz-Birkenau and reveal its secrets. They further warned that specific arrangements had been made in the camp for the annihilation of the Hungarian Jews. The precious information was disseminated without delay to the Western world. It is not clear whether it reached the prospective victims: All boarded in good faith the "resettlement trains" that carried them to the Auschwitz-Birkenau death camp, where most were immediately gassed. This specific story has been missing from most Israeli history textbooks in Hebrew. Following Winter's (2006) thesis, this paper tries to trace some of the official manipulation that were made in shaping the "right" form of remembrance.
\end{abstract}

Keywords: Auschwitz escape, memory, collective, information, early warning

\section{Introduction}

The struggle between the need to remember and the historical inevitability of forgetting is being discussed in this paper in face of the absence of the 1944 case of the successful escape from Auschwitz Birkenaudeath camp - a tale that has been missing in major history text books in Israel (Gutman \& Schatzker, 1984).

In the spring of 1944, the Auschwitz-Birkenau death camp was still a top secret of the Third Reich and the Nazis used numerous ploys to entice their prospective victims into it. Credible information emanating from within the camp was a rare commodity. On April 10, 1944, two Jewish prisoners of Slovak origin, Rudolf Vrba (originally named Walter Rosenberg) and Alfred Wetzler, succeeded in surprising the Germans: They managed to escape from the Auschwitz-Birkenau death camp - against all hopes. They had one mission in mind: to inform the world!

As shaven-headed Jewish inmates, clad in striped pajamas, with numbers tattooed on their arms, the two escapees expected little success in the outside world. Following their escape, the only administrative evidence of their existence was an international warrant about them, issued telegraphically and distributed to all stations of the Gestapo (Vrba, 1998). The warrant was also telegraphed to all stations of the Kripo (Kriminalpolizei-criminal police), the SD (Sicherheitsdienst-security service), and the Grepo (Grenzpolizei-border police). It even reached the desk of Heinrich Himmler, head of the SS and most likely

\footnotetext{
${ }^{*}$ This work was funded by Yad Susan Foundation, PEF. Ruth Linn, full professor, Faculty of Education, The University of Haifa.
} 
the desk of Adolf Eichmann, who was exactly, at that time, busy in completing the liquidation of the Hungarian Jewry (Pearlman, 1963).

After 11 perilous days spent walking and hiding, the escapees made it back to their native country, Slovakia. Almost at once, they managed to establish contact with members of the Slovak Jewish underground body named the "Working Group" which in fact regarded itself as the official leadership for the Slovak Jews.

At the time of the escape, Dr. Oscar Neumann, was the official chairman of the Jewish Council of Slovakia. Trained as a skilled lawyer, Neumann ordered to put the escapees in two separate rooms, where for three days each dictated his account to Dr. Neumann's aide. Oscar Krasniansky, an engineer who was also a good stenographer. The two transcripts, written in the Slovak language, were immediately translated into German and then hastily collated into a single report. To this day it is known as the Vrba-Wetzler report. To this, Krasniansky added a one-page introduction containing biographical notes on the anonymous escapees and vouching for the report's accuracy and authenticity. For the sake of security, the names of the escapees were not mentioned.

The escapees were able reconstructed a map of the camps from memory, the specifics of the Germans' method of mass murder, including tattooing, gassing, and cremation, and recounted events they had witnessed at the camp. They estimated that about 1.75 million Jews had been murdered from June 1942 to April 1944. Krasniansky added a supplement in which he urged the Allies to destroy the crematoria and the railroad lines leading to Auschwitz. Most significantly, the escapees informed the leaders that they had heard the Nazi guards talking about the need to expand the ramp and ovens at Auschwitz-Birkenausince all were awaiting a massive influx of "Hungarian salami". The two men also expressed their worries regarding 3,000 Czech Jews in the second "family camp" awaiting extermination (Gilbert, 1981).

On June 6, 1944, the day of the Normandy landings, two other Jewish inmates, Czeslaw Mordowicz and Arnost Rosin, reached Slovakia after having escaped from Auschwitz on May 27. They confirmed the prediction of Vrba and Wetzler regarding the "Hungarian Salami": They reported that in the two weeks prior to their escape on May 27, 1944, over 100,000 Hungarian Jews had reached Auschwitz-Birkenau, where most were immediately murdered in the gas chambers. Human fat was used to accelerate the burning of the corpses. Some were thrown alive to the fire.

When the escapees parted from their leaders, Krasniansky, arranged for them forged IDs (Walter Rosenberg became Rudolf Vrba) and assured them that the precious information would be disseminated without delay to the Western world. They fulfilled their promise. The report was the first document to reach the free world and be believed. Its accuracy and authenticity broke the barrier of skepticism and apathy that had existed up to that point. In the course of June 1944, the whole text, or partial extracts taken from it, reached the Czechoslovak embassy in exile in Switzerland, and soon thereafter the US State Department in Washington, the BBC in London, the King of Sweden, the British Parliament (June 27, 1944), and the United States Congress (June 28, 1944). On October 22 a complete copy finally reached the Vatican in Rome (Braham, 1982).

We know today that the Vrba's and Wetzler's critical and warning report was in the hands of the Hungarian Jewish leaders as early as April 28, 1944 or early May-about two weeks before the start of the deportations from Hungary. We know today that during May to June 1944, about 437,000 "uninformed" Hungarian Jews boarded in good faith the "resettlement trains" that carried them to the Auschwitz death camps, where most were immediately gassed. A study of numerous memoirs from a handful of surviving Hungarian deportees, even of those who arrived in Auschwitz as late as July 8,1944, reveals their absolute ignorance of 
their impending fate at the death camp. Elie Wiesel summarized it as follows: "We were taken just two weeks before D-Day and we did not know that Auschwitz existed... everyone knew except the victims" (Nicolls, 1993, p. 353).

The author became acquainted with this event through non-Israeli, a foreign filmmaker, Claude Lanzmann (1985) who considered Vrba's testimony on his escape central to the understanding of the Holocaust. To paraphrase Ricoeur (2004), this understanding is often the outcome of shared remembering of the past. But how collective is this remembering in Israel? How is it that the escape, the escapees, and the report are missing from the textbooks in the Hebrew language? Why is it missing from the shared remembering of the past?

In 1998, the author succeeded in breaking a 35 year silence by having Vrba memoirs published in Hebrew by the publishing house of the author's university — albeit not before it had been rejected by YadVashem.

Winter (2006) advises us to pay attention to the official manipulation in shaping the "right" form of remembrance. The tension between the "expert discourse" and the "survivor discourse" in the building of a national collective memory is described herein.

\section{The "Expert Discourse"}

Most historians agree that the report information did not reach the prospective victims although Vrba and Wetzler's alarming assessment had reached the Hungarian Jewish leaders as early as April 28, or at least no later than early May 1944-about two weeks before the deportation of the Hungarian Jews started (Bauer, 2001). Most historians agree that most of the war time Jewish leaders skillfully delivered the report to the western world and it had an immediate impact. The publication of portions of the report in the Swiss press in the final days of June 1944, and by the Western allies shortly thereafter, produced spontaneous international denunciation, which led to protests from the Pope, U.S. Secretary of State Cordell Hull, British Foreign Secretary Anthony Eden, the International Red Cross, and the King of Sweden. This "bombardment" on Admiral Miklos Horthy's conscience led, among other things, to his July 7, 1944 order to stop the deportations, which only went into effect on July 9. Almost 200,000 Jews in Budapest were thus saved from deportation (Braham, 1981; Gilbert, 1981).

But the mystery remained: Why did a detailed story on the Vrba-Wetzler's report disappear from the Israeli historiography? Is it an accident that the escapees and the report itself remain "inaccessible" or "invisible" for the Hebrew readers for over 35 years until the author (not a historian) brought it to the knowledge of the average Israeli Hebrew reader? How did it happen that its representation takes different forms of suppression: From information void to cloudingto marginalization - as if the escape ought to be preserved as a "family secret"? (Brown-Smith, 1998).

Most notable is the writers' oblivion regarding the escapees' names.

In his postwar memoirs, Dr. Neumann, the report's architect, clearly states that the two (unnamed) escapees alerted the Jewish leaders that the Nazis in the camp are awaiting the "Hungarian Jews". However, he does not explain why this alarming message is missing from the report. All we know is that Dr. Neumann fails to recall the escapees'names:

News about the horror of Auschwitz had reached Slovakia before, but it was vague... Who can reach death and come back? But one day this miracle happened. On that day, two young Jewish chaps, Slovakian-born, who had been deported in 1942 to Auschwitz, appeared. Their identity could be verified from their housing report (above the serial number tattooed on their arm). Like in a thriller, they had managed to escape and reached the Slovakian border, at the small town of Cadca". 
"These chaps", he further related, "did also report that recently an enormous construction activity had been initiated in the camp and very recently the SS often spoke about looking forward to the arrival of Hungarian salami". (Neumann, 1956, pp. 166, 178-181)

A similar form of social historical amnesia is found in the postwar testimony of Dr. Neumann's aid, Mr. Oscar Krasniansky who spent three intensive days interrogating the escapees and who arranged for them false papers with new names. In his depositions for the Eichmann trial, which are replete with other precise names and details, Krasniansky (1961), who was at the time a member of the Israeli legation in Germany, testified under oath that the report was written "by myself" in the spring of 1944, from the words of two young people who succeeded in escaping from the death camps of Auschwitz (Birkenau) in April, 1944.

In 1977, Dr. Livia Rothkirchen, an expert on the Slovak community, chooses to refer to the Auschwitz escapees as two young men who were the first prisoners to manage to escape from the camp (Krasnansky, 1961; Rothkirchen, 1977, p. 61). Historians of Hungarian origin often do likewise. Kohn and Cohen (1990) reported on "two young people who escaped from Auschwitz". Other scholars followed: In the 2001 Holocaust Encyclopedia compiled by Lacquer and Baumel (2001) refers to the escapees as "two Jewish prisoners [who] escaped from Auschwitz and passed to the papal representatives in Slovakia a detailed report on the killings in the camp" (p. xxxiv).

In 1998, Livia Rothkirchen, mentions the escapees and their report but fails to write the exact names of the escapees in her references. Vrba, surprisingly, is referred to as "Rudolf Rosenberg-Vrba". Her citing in Berenbaum and Peck's index has a highly interesting feature. While most of the names appear in full, for example, "Wiesel, Elie" all the names of the authors of the Auschwitz Report are abbreviated: "Mordowicz, C.", "Rosin, A.", "Wetzler, A.", and the name "Vrba" does not appear in the index at all! The reader is expected to guess whether he is to be found under "Rosenberg, W." (his pre-war name: Walter Rosenberg). This phenomenon is found only in Rothkirchen's chapter in this book. Another prominent Israeli Slovak historian, YehoshuaYelinek, labels the escapees in his 2003 Hebrew book as "Alfred Wetzler" and "Rudolf Rosenberg". Yet, this apparent confusion did not prevent this scholar from spelling Vrba's name correctly when attacking him in the press to belittle his heroism (Rothkirchen, 1998; Yelinek, 2003). The escapees' names are also missing an entry of their own in the Encyclopedia of the Holocaust (Gutman and Rozett, p. 1369). Their story is missing from their entry on Slovakia, their home country.

The real intellectual and practical beneficiaries of this misnaming, discrediting, marginalization, and omissions are the Holocaust deniers. While various neo-Nazi authors have made extraordinary efforts to delegitimize Vrba's testimony in his report and his memoirs, the belated acknowledgment from some Israeli Holocaust historians only serves to discredit Vrba and Wetzler even further in this respect. Arthur Butz, the notorious Holocaust denier who examined the postwar memoirs of Dr. Neumann, head of the Jewish Council of Slovakia at the time of the escape, argued that he noticed two crucial facts: First, Dr. Neumann does not mention the names of the escapees. Second, Dr. Neumann does not mention the Vrba-Wetzler report. He argued that if the contents of the Vrba-Wetzler report were true, Israeli historians would certainly know the escapees' names and would have publicized their report. So Butz concluded:

Neumann had been one of the leaders of the various Jewish Councils and resistance organizations in Slovakia. In Neumann's story the two young Slovak Jews appear on schedule in Slovakia ... Neumann gives the impression that he actually met these people ... His account does not... (Butz, 1975, pp. 95, 146) 
Butz further reminds Israeli Holocaust historians that "Vrba's affidavit [at Eichmann's trial] was rejected by the court on the grounds that there was no excuse for the prosecution not bringing him to testify" in person. To support the alleged fabrications in Vrba's story, Butz quotes Kulka's article, in which he discredits Rudolf Vrba for calling himself Rudi in his memoirs at a time when he was still named Walter Rosenberg. Indeed, in the course of his criticism, Kulka does not remind his readers that Vrba's memoirs had been written after the war, when Walter Rosenberg legalized his nom de guerre of Rudolf Vrba. Butz quotes Kulka: "In the book the other prisoners refer to him as Rudi". Butz further criticizes Kulka for revealing the names of Rosin and Mordowicz. He states, "I know nothing of these people [Rosin and Mordowicz] other than that they remained quiet about their heroic exploits for an even greater number of years than Vrba and Wetzler did" (Butz, 1975, pp. 96, 98, 99).

Robert Faurisson, the well-known French Holocaust denier, exploits the misnaming by Israeli Holocaust historians when he comes to explain the Auschwitz myth.

We have known for some time that the Auschwitz myth is of an exclusive Jewish origin... the principal authors of the creation and the peddling of the "rumor of Auschwitz" have been, successively, two Slovaks, Alfred Wetzler (or Weczler) and Rudolf Vrba (or Rosenberg or Rosenthal)... It is remarkable that from beginning to end, that story comes from essentially or perhaps even exclusively Jewish sources. Two Jewish liars (Vrba and Wetzler) from Slovakia convinced or seem to have convinced other Jews from Hungary, Switzerland, the United States, Great Britain and Poland. This is not a conspiracy or a plot; it is the story of the birth of a religious belief: the Myth of Auschwitz... (Faurisson, R. 1986, pp. 400-401)

The atmosphere of suppression from "above" seems to affect the historians' memory as well. Thus it happens that the Israeli public is mistakenly informed that Vrba "arrived" in Israel (Bauer, 2006, p.160), while in fact he alone among the escapees also heroically defected to the west in 1958, long after the war ended. They are further informed that in 1958 Vrba worked at the Weizmann Instituteof Science - and that he left Israel because he probably did not get along with his employers there (Bauer, 2006), when in fact he never spent a single day there.

It seems that the long term attempts to suppress an heroic tale - often results in grave mistakes. The letter of recommendation on Vrba's behalf sent to the University of Haifa states that he deserves the honorary doctorate even though "Vrba, did not fight with a gun in his hand but escaped in order to testify and this is what he did". The writer seem to forget or simply did not remember that Vrba fought as a machine-gunner in a unit commanded by Milan Uher and was awarded the Czechoslovak Medal for Bravery, the Order of Slovak National Insurrection and the Order of Meritorious Fighter.

\section{The "Survivor Discourse"}

Following the honouring of Vrba by the university of Haifa, leading Israeli historians from Slovak origin joined forces and hastily compiled a volume of articles in Hebrew (Bauer, 2001). In the hostile introduction Vrba is criticized for having an independent mind regarding the war events (mainly his criticism of his war time leaders).

The heroism of this person, who, together with the late Alfred Wetzler, was among the first to escape from Auschwitz, is beyond doubt. But the fact is that, just because he was an Auschwitz prisoner endowed with personal heroism, he has crowned himself as knowledgeable to judge all those involved in the noble work of rescue, and accuse them falsely, deeply

\footnotetext{
${ }^{1}$ Professor Bauer's letter of recommendation addressed to Haifa University is dated April 1, 1998.
} 
disturbs us, the Czech community. (Amir, in Bauer 2001, pp. 11-12)

As to their credentials, the volume's participants conclude their introduction as follows:

...We, Czechoslovakian descendants, who personally experienced [the war], cannot remain silent in face of these false accusations. With all its horrors, this history is a narrative: we need to have a story teller, and a story teller has to stand somewhere. We are not just telling history, we are telling memories and firsthand experiences. These are our memories and experiences. Our position in this regard is very clear. (Amir, in Bauer 2001, pp. 11-12)

Is Professor Jay Winter right when he claims that such writings from "above"-aims at the manipulation and shaping the "right" form of remembrance?

Dr. Gila Fatran, an Israeli Holocaust historian from Slovak origin and a Holocaust survivor, who did her $\mathrm{Ph} . \mathrm{D}$. thesis on the wartime Slovak Jewish leadership under the supervision of Professor Bauer, is a central contributer to this book. She insists that the Slovak wartime leaders disseminated warnings of the Vrba-Wetzler report "by dispatching messengers on slow Slovak trains going to towns and small villages all over the country". She claims that these messengers were mainly members of the Zionist movement: "Youth movement activists undertook to relay messages to provincial towns so as to warn Jews of the imminent danger"-but no one believed them.

Indeed, the Zionist youth movement was an unbelievably heroic group of youngsters who deserve all the honor in the nation's collective memory. But alas-their heroic rescue mission was not related to the Vrba-Wetzler report and its specific information.

Moreover, we know today that some Jewish leaders who possessed the report, preferred not to disseminate it in order not to create panic (Braham, 1981).

Fatran (1994) is finally forced to admit that the information dispatched by the messengers she mentioned "was warning against deportations, not against certain death". As a result of the above weak arguments, Fatran chooses to conclude that the report, was not relevant:

There was no need to become acquainted with the details of the genocidal process per se in order to realize that Europe contained murderers of Jews. Anyone keeping track of world events through foreign sources (such as BBC broadcasts, although listening to them was forbidden, and word of mouth reports) could have known this; it does not include the countless Polish refugees who escaped to Hungary bringing this news.

Fatran is not alone. Prof. Gutman, who was also the chief historian of YadVashem, saw nothing amiss in keeping the public ignorant about the Vrba-Wetzler report. In 2005, seven years after the arrival of Vrba in Israel, he presented his clear position on this topic: "Vrba is not the only one we didn't discuss. In a textbook you summarize, and put in only the most fundamental things". Prof. Dalia Ofer, head of the Institute for Contemporary Jewish Studies at the Hebrew University in Jerusalem, joined him, saying: "If I had to think of the 10 things that should be in a Holocaust textbook, this escape wouldn't necessarily be one of them. Primo Levi, a discussion of the Auschwitz camp itself—-these would go in before that" (Dromi, 2005).

\section{Conclusion}

To this day, the author unsure as to which is the more striking element of this story: The fact that such a brazen escape from such a central and impossible location as Auschwitz-Birkenau was even feasible, or the fact that this story of escape and its heroes has themselves "escaped" from history books in Israel. When asked "why weren't we told about this heroic escape and report in school?". The author was told by various historians 
that the opinions of Rudolf Vrba are not appropriate for official representation given that they are a collection of "musings on historical matters" and with respect to "Linn's assertions that the subject is not taught in schools, there is no truth to them" (Bauer, 2004).

The facts, however, said otherwise. Upon the Hebrew language publication of Vrba's memoir of his escape, the phone in my office began ringing non-stop. People from all walks of life were hurrying to tell me that they too had never before heard the story — not in school, not in their children's or grandchildren's schoolbooks, not on trips to Auschwitz-Birkenau, not even during official Holocaust Remembrance Day ceremonies. Even students of history at various Israeli universities were among the callers. "Who knows", one of them confided with me, "if you hadn't brought the last surviving escapee to Israel, it's possible that we wouldn't know of this amazing heroic tale today".

Since the 1998 publication of the Hebrew version of Vrba's memoirs, the honorary doctorate was awarded to him by the University of Haifa and the publication of author's book "Escaping Auschwitz" (Linn, 2004), some interesting changes have occurred. Among the positive changes is the inclusion of Vrba's and Wetzler's names in the new Yad Vashem Museum, the inclusion of the Vrba-Wetzler report in some of the Israeli text books in Hebrew. Finally, Israelis intending to visit Auschwitz-Birkenau can now be told this tale beforehand, and locate the report as well.

Further studies are needed as to why and how the historians and archivists at Yad Vashem never availed of the money to translate the 30-page report into Hebrew, and what prevented the report being placed in a separate file of its own in the Yad Vashem archive - with its proper title.

Hanna Horowitz, a history teacher from Jerusalem-summarizes these future lines of research in a letter she wrote in 1998 - after learning for the first time in her life that an escape of Jewish inmates from Auschwitz-Birkenau, had ever occurred:

How is it possible that such a book was not published by the University History Department? It is beyond my understanding that Yad Vashem, Lochamei Hagetaot, or any other respected publishing house found no interest (all these years) in publishing the book. Am I to believe that this is accidental? (Ha'aretz, 1998)

\section{References}

Amir, Y. (2001). Introduction. In Y. Bauer (Ed.), Manhigutba'et Metsuka: Kvutsat Ha'avodabe Slovakia 1942-1944 (Leadership in Time of Distress: The Working Group in Slovakia, 1942-1944) (p. 141). Kibbutz Dalia: Ma'arechet.

Bauer, Y. (2001). Hearotleduach Auschwitz shel Rudolph Vrba (Comments of Rudolph Vrba's Auschwitz Report). In Y. Bauer (Ed.), Manhigutba'et Metsuka: Kvutsat Ha'avodabe Slovakia 1942-1944 (Leadership in Time of Distress: The Working Group in Slovakia, 1942-1944) (p. 141). Kibbutz Dalia: Ma'arechet.

Bauer, Y. (2002). Rethinking the Holocaust. New Haven, CT: Yale University Press.

Bauer, Y. (2004). Response to Ruth Linn (Tshuvalerutlinn). Theory and Criticism, 24(2004), 185-190.

Bauer, Y. (2006). The Auschwitz Protocols (Haprotokolimshel Auschwitz). Yalkut Moreshet (pp. 164-167).

Braham, R. L. (1981). The politics of genocide: The Holocaust in Hungary (pp. 721-22). New York: Columbia University Press.

Brown-Smith, N. (1998). Family secrets. Journal of Family Issues, 19(1), 20-42.

Butz, A. (1975). The hoax of the twentieth century. Richmond: Historical Review Press.

Dromi, U. (2005). Deaf ears blind eyes. Retrieved from http://www.haaretz.com/

Fatran, G. (1994). The "Working Group". Holocaust and Genocide Studies, 8, 183.

Fatran, G. (1995). Letters to the Editor: Response. Holocaust and Genocide Studies, 9(2), 272.

Faurisson, R. (1986). How the British obtained the confessions of Rudolf Hoss. Journal of Historical Review, 7(4), 400-401.

Gilbert, M. (1981). Auschwitz and the Allies. New York: Holt, Rinehart and Winston.

Gutman, I., \& Rozett, R. (1990). Encyclopedia of the Holocaust. New York: Macmillan. 
Gutman, I., \& Schatzker, C. (1984). The Holocaust and its significance. Jerusalem: ZalmanShazar Center: Historical Society of Israel.

Kohn, Y., \& Cohen, A. (1990). Auschwitz protocols and the expulsion of the Hungarian Jews. Dapim: Studies on the Shoah, 8 , 205.

Krasnansky, O. (1961). A declaration under Oath. Cologne: Israel Consulate.

Lacquer, W., \& Baumel, J. T. (2001). Holocaust Encyclopedia. New Haven: Yale University Press.

Lanzman, C. (1985). Shoah. New Yorker Films.

Linn, R. (2004). Escaping Auschwitz. Ithaca: Cornell University Press.

Neumann, O. (1956). ImSchatten des Todes; einTatsachenberichtvomSchicksalskampf des slovekischenJudentums (p. 166). Tel-Aviv: Edition Olamenu.

Nicolls, W. (1993). Christian Anti Semitism: A history of hate. New Jersey: Northvale.

Pearlman, M. (1963). The capture and trial of Adolf Eichmann (p. 357). New York: Simon and Schuster.

Ricoeur, P. (2004). Memory, history, forgetting. Chicago: University of Chicago Press.

Rothkirchen, L. (1961). Hurbanyahadut Slovakia (The destruction of Slovakian Jewry) (p. 427). Jerusalem: YadVashem.

Rothkirchen, L. (1998). Czech and Slovak Wartime Jewish leadership: Variants in strategy and tactics. In The Holocaust and History: The Known, The Unknown, The Disputed and The Reexamined (pp. 636, 640, 830, 833, 835). Bloomington, IN: Indiana University Press.

Vrba, R. (1998). The preparations for the Holocaust in Hungary: An eyewitness account. In R. Brahan, \& S. Miller (Eds.), The Nazis' Last Victims: The Holocaust in Hungary (pp. 72-73). Detroit: Wayne University Press.

Vrba, R. (2002). I Escaped from Auschwitz (pp. 327-363). Fort Lee, NJ: Barricade Books.

Winter, J. (2006). Remembering war: The great war between memory and history in the 20th century. New Haven: Yale University Press.

Yelinek, Y. (2003). HagolaLeragleiHakapatim: YehudieKarpatoRusoUmuskshavo 1848-1948. Tel Aviv: Tel Aviv Publishing House. 